\title{
Low serum total nitrite and nitrate levels in severe leptospirosis
}

Thilini Kalugalage ${ }^{1}$, Chaturaka Rodrigo ${ }^{2}$, Thamal Vithanage ${ }^{2}$, Pranitha Somaratne ${ }^{3}$, H Janaka De Silva ${ }^{4}$, Shiroma Handunnetti ${ }^{1}$ and Senaka Rajapakse ${ }^{2^{*}}$

\begin{abstract}
Background: The relationship between inducible nitric oxide synthatase activity and disease severity in leptospirosis is unclear. Nitric oxide is converted to nitrites and nitrates, thus nitrite and nitrate levels $\left(\mathrm{NO}^{\times}\right)$in serum are considered surrogate markers for nitric oxide. $\mathrm{NO}_{x}$ are excreted through the kidneys, and elimination is diminished in renal impairment. We assessed the correlation of $\mathrm{NO}_{x}$ with disease severity in patients with leptospirosis, compared with healthy controls and non-leptospirosis fever patients.

Methods: All patients admitted over a two-month period to the National Hospital, Colombo, Sri Lanka with a clinical picture suggestive of leptospirosis were included. Leptospirosis was confirmed by the microscopic agglutination test (titre $\geq 400$ ). Severe leptospirosis was defined by the presence of two or more of the following criteria: jaundice (bilirubin $>51.3 \mu \mathrm{mol} / \mathrm{l}$ ), oliguria (urine output $<400 \mathrm{ml} /$ day), serum creatinine $>133 \mu \mathrm{mol} / \mathrm{l}$ or blood urea $>25.5 \mathrm{mmol} / \mathrm{l}$, or the presence of organ dysfunction. Non-leptospirosis fever patients and healthy volunteers were used as control groups. $\mathrm{NO}_{x}$ levels were measured using a modified Griess reaction.
\end{abstract}

Results: Forty patients were confirmed as having leptospirosis and 26 of them had severe disease. $\mathrm{NO}_{x}$ levels were significantly higher in confirmed leptospirosis patients compared to healthy controls, MAT equivocal patients and non-leptospirosis fever patients $(\mathrm{p}<0.001)$. $\mathrm{NO}_{x}$ concentrations were also significantly higher in patients with severe compared to mild leptospirosis $(\mathrm{p}<0.001)$. Once $\mathrm{NO}_{x}$ levels were corrected for renal function, by using the ratio $\mathrm{NO}_{x} /$ creatinine, $\mathrm{NO}_{x}$ levels were actually significantly lower in patients with severe disease compared to other patients, and values were similar to those of healthy controls.

Conclusions: We postulate that high NOx levels may be protective against severe leptospirosis, and that finding low NOx levels (when corrected for renal function) in patients with leptospirosis may predict the development of severe disease and organ dysfunction.

Keywords: Leptospirosis, Nitric oxide, Nitrate, Nitrite, Severity, Creatinine

\section{Background}

Leptospirosis is a zoonotic illness that has a high morbidity and mortality in the tropics [1]. It is caused by a spirochaete of the genus Leptospira, which is now found to have at least nine pathogenic species and over 250 serovars. The global burden of leptospirosis is difficult to quantify due to under-reporting and difficulties in establishing a serological diagnosis. However, it is estimated that in endemic areas (localized geographical

\footnotetext{
* Correspondence: senaka.ucfm@gmail.com

${ }^{2}$ Department of Clinical Medicine, Faculty of Medicine, University of Colombo, Colombo, Sri Lanka

Full list of author information is available at the end of the article
}

areas in Central America, Indian subcontinent, Oceania, and the Caribbean), the incidence of leptospirosis can be as high as 25 clinical infections per 100,000 of population per year (in contrast to 1 per 100,000 per year in non-endemic areas) [2].

The majority of infections are asymptomatic or may pass off as a flu like illness. However, severe leptospirosis can be fatal. Severe leptospirosis is associated with adult respiratory distress syndrome (ARDS), pulmonary haemorrhage, acute kidney injury, liver impairment, and multi-organ dysfunction syndrome (MODS) [3,4]. The case fatality in severe leptospirosis (Weil's disease) can be as high as $40 \%[5]$.

\section{Biomed Central}


Predictors of disease severity can be useful to the clinician for anticipating complications. Factors predicting mortality in severe leptospirosis as reported in various studies worldwide have been reviewed by Rajapakse et al. [6] under the categories of predisposition, insult, response and organ dysfunction (similar to the PIRO model used to predict mortality in severe sepsis). Although there was insufficient data to develop a scoring system for mortality prediction, it was noted in this review that serum markers of acute inflammation (tumour necrosis factor- $\alpha$, interleukin-1, interleukin-6) have not been adequately assessed as prognostic markers. These pro-inflammatory cytokines lead to an increase in the activity of inducible nitric oxide synthatase (iNOS) to synthesize nitric oxide (NO) which is toxic to the bacterium. The role of iNOS and NO production in inflammation has not been clearly determined in leptospirosis; in fact its significance in severe sepsis [7] and other infections such as malaria [8-11] is subject to much debate $[12,13]$. While its primary role is to combat infection, NO levels have been shown to be elevated in severe leptospirosis [14], leading to the postulate that high NO levels may be involved in the pathogenesis of organ dysfunction in leptospirosis. On the other hand, increased iNOS activity may actually protect against organ dysfunction.

$\mathrm{NO}$ is an extremely volatile compound that is difficult to measure in serum. It is quickly converted to nitrite $\left(\mathrm{NO}_{2}{ }^{-}\right)$and nitrate $\left(\mathrm{NO}_{3}{ }^{-}\right)$[15]. It is estimated that more than $95 \%$ of nitrite in whole blood gets converted to nitrate within one hour [16]. Thus, the total blood levels of nitrite and nitrate $\left(\mathrm{NO}_{\mathrm{x}}\right)$ could be considered to be a surrogate marker of serum $\mathrm{NO}$ levels. $\mathrm{NO}_{\mathrm{x}}$ levels in blood are affected by the amount of ingested nitrates; to control for this, measurements should ideally be made after an overnight fast [17]. Furthermore, $\mathrm{NO}_{\mathrm{x}}$ is excreted renally, thus $\mathrm{NO}_{\mathrm{x}}$ clearance is reduced in the presence of renal impairment [18]. To correct for this, the use of the ratio of serum $\mathrm{NO}_{x} /$ creatinine has been suggested to be a more accurate marker of iNOS activity than crude $\mathrm{NO}_{\mathrm{x}}$ levels, and was used in the study by Anstey et al. [17] to correct $\mathrm{NO}_{\mathrm{x}}$ levels for renal function in patients with malaria. Although other factors could influence creatinine levels, and therefore this correction factor too, creatinine levels are the standard index used for assessment of renal dysfunction in acute kidney injury [19]. Therefore the formula $\mathrm{NO}_{\mathrm{x}}$ /creatinine is currently the only practical formula available to correct $\mathrm{NO}_{\mathrm{x}}$ levels for renal function.

We previously demonstrated through a preliminary study that serum nitrite levels are elevated in patients with acute leptospirosis compared to healthy controls [20]. However, the sample size was inadequate to determine a correlation with disease severity. The aim of this study was to determine the relationship between $\mathrm{NO}_{\mathrm{x}}$ (i.e., total nitrite and nitrate) levels in the blood (as a marker of iNOS activity) and disease severity in leptospirosis. If such a correlation exists, $\mathrm{NO}_{\mathrm{x}}$ could potentially be useful as a prognostic marker.

\section{Methods \\ Objectives}

The objectives of our study were to a) determine serum $\mathrm{NO}_{\mathrm{x}}$ (nitrate and nitrite) levels in patients with confirmed leptospirosis, b) compare serum $\mathrm{NO}_{\mathrm{x}}$ levels in leptospirosis patients with mild and severe disease, healthy controls and non-leptospirosis fever patients (NLFs), and c) seek a correlation between serum $\mathrm{NO}_{\mathrm{x}}$ levels and disease severity after correcting for impaired renal clearance.

\section{Participants}

Patients suspected to have leptospirosis were selected from the National Hospital of Sri Lanka (NHSL). The NHSL is the premier tertiary care center in Sri Lanka, with a bed strength of over 3600. It is one of the few state sector centers with facilities for haemodialysis in the country, and most patients with acute kidney injury are transferred to NHSL for further management. It is also the major hospital that covers the heavily populated Western Province which is an endemic area for leptospirosis [21]. The annual incidence of leptospirosis in the Western Province for the year 2011 was 22 per 100,000 population.

All patients with a febrile illness who were clinically suspected of having leptospirosis admitted to medical wards in NHSL during a two-month period from 23rd June to 27th August 2010 were included in to the study, after obtaining informed consent. The clinical criteria to define a probable case of leptospirosis were adopted from the World Health Organization (WHO) surveillance criteria [22]. Microscopic Agglutination Titre (MAT) is the most widely used confirmatory test for leptospirosis, although the duration that MAT remains positive after infection is not clearly known [23]. Nonetheless a MAT titre of $>400$ is generally considered to indicate acute infection even in areas of high endemicity, in the setting of a clinical diagnosis of leptospirosis. Based on MAT results, patients were retrospectively categorized as confirmed leptospirosis (MAT titre $\geq 400$, MAT equivocal (MAT titre 100 and 200), and nonleptospirosis fever (MAT negative). Healthy volunteers (MAT negative) were selected as controls.

Serial haematological and serum biochemical measurements of patients were made during the illness, and included leukocyte and platelet counts, blood culture, erythrocyte sedimentation rate (ESR), serum potassium, serum sodium, aspartate aminotransferase, 
alanine aminotransferase, creatinine, blood urea and indirect, direct and total bilirubin levels.

Patients with severe leptospirosis were defined as those presenting with acute fever and clinical symptoms compatible with leptospirosis (confirmed serologically by a positive MAT result) with two or more of the following criteria: jaundice (bilirubin $>51.3 \mu \mathrm{mol} / \mathrm{l}$ ), oliguria (urine output $<400 \mathrm{ml} /$ day), serum creatinine $>133 \mu \mathrm{mol} / \mathrm{l}$ or blood urea $>25.5 \mathrm{mmol} / \mathrm{l}$ [14], or the presence of acute organ dysfunction.

\section{Determination of serum $\mathrm{NO}_{\mathrm{x}}$ levels}

Serum $\mathrm{NO}_{\mathrm{x}}$ levels were determined in all patients who were recruited in to the study. $\mathrm{NO}_{x}$ levels were measured in blood obtained early morning. Total $\mathrm{NO}_{\mathrm{x}}$ levels were used as a surrogate marker for serum nitric oxide levels [24].

The blood samples collected were centrifuged, and separated sera were stored at $-20^{\circ} \mathrm{C}$. During analysis, the serum samples were first thawed, then deproteinized by adding zinc sulfate. Deproteinization is a necessary step in the measurement of serum nitrite concentrations [25]. Ten microlitres of $1.5 \mathrm{~g} / \mathrm{mL}$ zinc sulphate solution was added to $1 \mathrm{~mL}$ of serum, vortexed for 1 minute, and centrifuged at $10,000 \mathrm{~g}$ for 10 minutes at room temperature $\left(\mathrm{RT}=25^{\circ} \mathrm{C}\right.$, i.e., the controlled temperature in the laboratory). The supernatant was pipetted out and centrifuged again at 10,000 $g$ for 10 minutes. The clear serum $(100 \mu \mathrm{L})$ was applied in duplicate to a 96-well ELISA plate, $100 \mu \mathrm{L}$ of vanadium (III) chloride $(8 \mathrm{mg} /$ $\mathrm{mL}$ ) was added to each well (for reduction of nitrate to nitrite) followed by the addition of $100 \mu \mathrm{L}$ of Griess reagent (equal mixture of $1 \%$ sulphanilamide in $5 \%$ phosphoric acid and $0.1 \% \mathrm{~N}$-(1-naphthyl) ethylenediamine hydrochloride in distilled water). The plates were incubated for 30 minutes at RT and the optical density was measured at $540 \mathrm{~nm}$ using the ELISA reader (Bio-Tek Instruments INC, USA). A two-fold dilution series $(0.193-100 \mu \mathrm{M})$ of $\mathrm{NaNO}_{2}$ was prepared from $100 \mu \mathrm{M} \mathrm{NaNO}{ }_{2}$ solution using distilled water. Each dilution $(100 \mu \mathrm{L})$ was mixed with an equal volume of Griess reagent, and the optical density (OD) was measured at $540 \mathrm{~nm}$. A standard curve was plotted against optical density and $\mathrm{NaNO}_{2}$ concentration. Intra-assay coefficient of variability (CV) was $6.55 \%$ and inter-assay $\mathrm{CV}$ was $8.62 \%$, which indicated good precision and repeatability.

\section{Ethics}

Ethics approval was obtained from the Ethics Review Committee of the Faculty of Medicine, University of Colombo and the Ethics Review Committee of the NHSL. Informed written consent was obtained from all patients and healthy controls prior to recruitment to the study.

\section{Statistical methods}

Statistical analysis was performed using SPSS $^{\circledR}$ version 17.0. Results were expressed as mean \pm SD. Data were analyzed by applying a one-way ANOVA with the Bonferonni/Dunn post-hoc correction for multiple comparisons. Multivariate regression analysis was performed to determine the relationship between $\mathrm{NO}_{\mathrm{x}}$ and other biochemical markers of severity. Statistical significance was defined as $\mathrm{p}<0.05$.

\section{Results}

\section{Patient categorization}

On the basis of clinical features, 85 patients were recruited to the study with probable leptospirosis. Of these, 40 were confirmed as leptospirosis with MAT (titre of $\geq 400$ ). There were also 27 patients who had equivocal MAT titers and 18 with non-leptospirosis fever (MAT negative). Twenty three MAT negative healthy individuals were also recruited as controls. The mean \pm SD of the duration between onset of symptoms and obtaining serum samples in the confirmed leptospirosis patients was $10.6 \pm 3.9$ days. The baseline characteristics of these groups are shown in Table 1.

Of the 40 patients with confirmed leptospirosis, 26 were categorized as having severe disease according to the criteria mentioned above. One patient with severe disease died and all others survived. The laboratory investigations for each category of patients and for nonleptospirosis fever patients are summarized in Table 2.

\section{Comparison of uncorrected serum $\mathrm{NO}_{\mathrm{x}}$ levels}

We first compared $\mathrm{NO}_{\mathrm{x}}$ levels of confirmed leptospirosis patients (mild and severe) MAT equivocal patients, NLF patients, and healthy controls (Table 3 and Figure 1, Table 4). Significantly higher $\mathrm{NO}_{\mathrm{x}}$ levels were observed in confirmed leptospirosis patients when compared against healthy controls, MAT equivocal patients and non-leptospirosis fever patients $(\mathrm{p}<0.001) . \mathrm{NO}_{\mathrm{x}}$ concentrations in patients with severe leptospirosis were also significantly higher than in those with mild leptospirosis $(p=0.003)$. There was no significant difference in values between MAT equivalent patients and non-leptospirosis fever patients. Notably, many of these differences were not observed when the serum nitrite levels alone were considered.

\section{Comparison of NOx levels corrected for impaired renal function}

In order to correct for renal impairment, we calculated the serum $\mathrm{NO}_{\mathrm{x}}$ /creatinine ratio in each of the groups. The comparisons of these groups are shown in Table 5 
Table 1 Comparison of age and gender among the study groups

\begin{tabular}{llll}
\hline & Confirmed leptospirosis patients & MAT equivocal patients & Non-leptospirosis fever controls \\
\hline Number of patients & 40 & 27 & 18 \\
\hline MAT titre & $\geq 400$ & $100-200$ & 0 \\
\hline Mean age \pm SD (years) & $39.7 \pm 14.6$ & $38.4 \pm 15.2$ & $37.8 \pm 13.8$ \\
\hline Gender (Male:Female) & $19: 1$ & $26: 1$ & $8: 1$ \\
\hline
\end{tabular}

and Figure 2 (also Table 6). Corrected $\mathrm{NO}_{\mathrm{x}}$ were lower among patients confirmed to have leptospirosis compared to healthy controls, although the difference was marginal. There was no significant difference seen in corrected $\mathrm{NO}_{\mathrm{x}}$ levels among confirmed leptospirosis patients, MAT equivocal patients and NLFs.

The most significant finding was that corrected $\mathrm{NO}_{\mathrm{x}}$ levels were markedly lower among patients with severe leptospirosis compared with both mild leptospirosis and MAT-equivocal patients. On the other hand, no difference was seen in corrected $\mathrm{NO}_{\mathrm{x}}$ levels in severe leptospirosis patients, healthy controls and NLF patients. Corrected $\mathrm{NO}_{\mathrm{x}}$ levels were significantly lower among healthy controls compared with mild leptospirosis patients and MAT equivocal patients, but no significant difference was shown between healthy controls and NLFs.

\section{Discussion}

Elevation of serum $\mathrm{NO}_{\mathrm{x}}$ levels during acute infections such as dengue, malaria and leptospirosis has been shown in previous studies, however the main criticism of these studies has been the lack of correction of $\mathrm{NO}_{\mathrm{x}}$ concentrations for renal function. As mentioned above, $\mathrm{NO}_{\mathrm{x}}$ is excreted predominantly by the kidneys, and $\mathrm{NO}_{\mathrm{x}}$ levels have been shown to be elevated in the presence of renal impairment.

We demonstrated that crude $\mathrm{NO}_{\mathrm{x}}$ levels are significantly elevated in leptospirosis, with higher levels correlating with severity of the illness. However, once $\mathrm{NO}_{\mathrm{x}}$ levels were corrected for renal function, they were significantly lower in severe leptospirosis. If $\mathrm{NO}_{\mathrm{x}}$ levels reflect iNOS activity, this finding suggests that iNOS activity is diminished in patients developing severe disease. Furthermore, the results suggest that iNOS activity is similar in severe leptospirosis and healthy controls despite the heavy inflammatory response in the former group. We postulate that this indicates that a blunted iNOS response is seen in severe leptospirosis; whether this is the result of the inflammatory response that occurs, or whether a diminished iNOS response plays a role in the genesis of severe leptospirosis and organ dysfunction remains to be elucidated. Conversely, it is possible that higher levels of NOx are protective against organ dysfunction. Admittedly, the relationship between iNOS activity and inflammation is extremely complex.

Nonetheless, similar patterns have been seen in malaria. Al Yaman et al. [10] described an association between high levels of $\mathrm{NO}_{\mathrm{x}}$ levels and coma in children with cerebral malaria. Similarly Kremsner et al. [9] showed that higher levels of plasma NO were seen in severe malaria; however they also demonstrated that higher levels of NO was associated with accelerated recovery. The criticism of both these studies was that crude NO levels were considered, and no correction was made for deranged renal function (serum creatinine levels in the patients were not provided), and that the elevated NO levels could simply be related to reduced excretion of NO due to impairment of renal function [13]. In fact, Anstey et al. [11] demonstrated that when $\mathrm{NO}_{\mathrm{x}}$

Table 2 Laboratory parameters of mild and sever leptospirosis patients, MAT equivocal patients and non-leptospirosis fever controls (univariate analysis)

\begin{tabular}{lllll}
\hline Laboratory parametert & $\begin{array}{l}\text { Patients with severe } \\
\text { leptospirosis }\end{array}$ & $\begin{array}{l}\text { Patients with mild } \\
\text { leptospirosis }\end{array}$ & $\begin{array}{l}\text { MAT equivocal } \\
\text { group }\end{array}$ & $\begin{array}{l}\text { Non-leptospirosis } \\
\text { fever patients }\end{array}$ \\
\hline WBC-highest $\left(\mathrm{cell} / \mathrm{s} / \mathrm{mm}^{3}\right)$ & $15461 \pm 9625$ & $11418 \pm 5071$ & $12170 \pm 3637$ & $11650 \pm 2703$ \\
\hline Platelets-lowest $\left(\mathrm{cell} / \mathrm{s} / \mathrm{mm}^{3}\right)$ & $114714 \pm 91166$ & $142154 \pm 72178$ & $\mathrm{NA}$ & $\mathrm{NA}$ \\
\hline ESR-highest $(\mathrm{mm} / \mathrm{hour})$ & $59.8 \pm 42.7$ & $45.6 \pm 41.1$ & $47.6 \pm 40.8$ & $45.3 \pm 23.9$ \\
\hline Bilirubin-total $(\mu \mathrm{mol} / \mathrm{l})$ & $159.0 \pm 140.2^{*}$ & $49.7 \pm 37.2$ & $52.1 \pm 40.6$ & $61.29 \pm 69.5$ \\
\hline AST $(\mathrm{U} / \mathrm{L})$ & $138.6 \pm 90.0$ & $97.5 \pm 75.3$ & $140.9 \pm 141.7$ & $89.8 \pm 68.7$ \\
\hline ALT $(\mathrm{U} / \mathrm{L})$ & $105.4 \pm 58.0$ & $94.6 \pm 63.3$ & $89.7 \pm 59.9$ & $62.4 \pm 27.7$ \\
\hline Blood urea $(\mathrm{mmol} / \mathrm{l})$ & $16.0 \pm 8.3^{*}$ & $5.7 \pm 5.4$ & $6.7 \pm 3.9$ & $6.7 \pm 4.6$ \\
\hline Serum creatinine $(\mu \mathrm{mol} / \mathrm{l})$ & $520.4 \pm 200.4^{*}$ & $113.3 \pm 15.6$ & $153.6 \pm 142.9$ & $140.1 \pm 82.1$ \\
\hline
\end{tabular}

† mean \pm SD; NA - not available; * differed at a statistically significant level $(p<0.001)$ from patients with mild disease and MAT equivocal patients. 
Table 3 ANOVA post-hoc comparison using Bonferonni correction comparing uncorrected NOx in the different groups

\begin{tabular}{|c|c|c|c|c|}
\hline (I) Category & (J) Category & Mean difference (I-J) & Std. error & Sig. \\
\hline \multirow[t]{4}{*}{ NLF } & MAT eq & -.509167 & 2.661898 & 1.000 \\
\hline & Mild lepto & -7.622690 & 3.117296 & .162 \\
\hline & Severe lepto & $-18.547372^{*}$ & 2.682296 & .000 \\
\hline & Controls & 7.444000 & 2.727634 & .075 \\
\hline \multirow[t]{4}{*}{ MAT equivocal } & NLF & .509167 & 2.661898 & 1.000 \\
\hline & Mild lepto & -7.113524 & 2.881040 & .152 \\
\hline & Severe lepto & $-18.038205^{*}$ & 2.403658 & .000 \\
\hline & Controls & $7.953167^{*}$ & 2.454149 & .016 \\
\hline \multirow[t]{4}{*}{ Mild leptospirosis } & $\mathrm{NLF}$ & 7.622690 & 3.117296 & .162 \\
\hline & MAT eq & 7.113524 & 2.881040 & .152 \\
\hline & Severe lepto & $-10.924681^{*}$ & 2.899897 & .003 \\
\hline & Controls & $15.066690^{*}$ & 2.941883 & .000 \\
\hline \multirow[t]{4}{*}{ Severe leptospirosis } & NLF & $18.547372^{*}$ & 2.682296 & .000 \\
\hline & MAT eq & $18.038205^{*}$ & 2.403658 & .000 \\
\hline & Mild lepto & $10.924681^{*}$ & 2.899897 & .003 \\
\hline & Controls & $25.991372^{*}$ & 2.476259 & .000 \\
\hline \multirow[t]{4}{*}{ Healthy Controls } & NLF & -7.444000 & 2.727634 & .075 \\
\hline & MAT eq & $-7.953167^{*}$ & 2.454149 & .016 \\
\hline & Mild lepto & $-15.066690^{*}$ & 2.941883 & .000 \\
\hline & Severe lepto & $-25.991372^{*}$ & 2.476259 & .000 \\
\hline
\end{tabular}

NLF: Non-leptospirosis fever, MAT eq: MAT equivocal patients, lepto: leptospirosis. Sig: significance. ${ }^{*}$ denotes statistically significant differences.

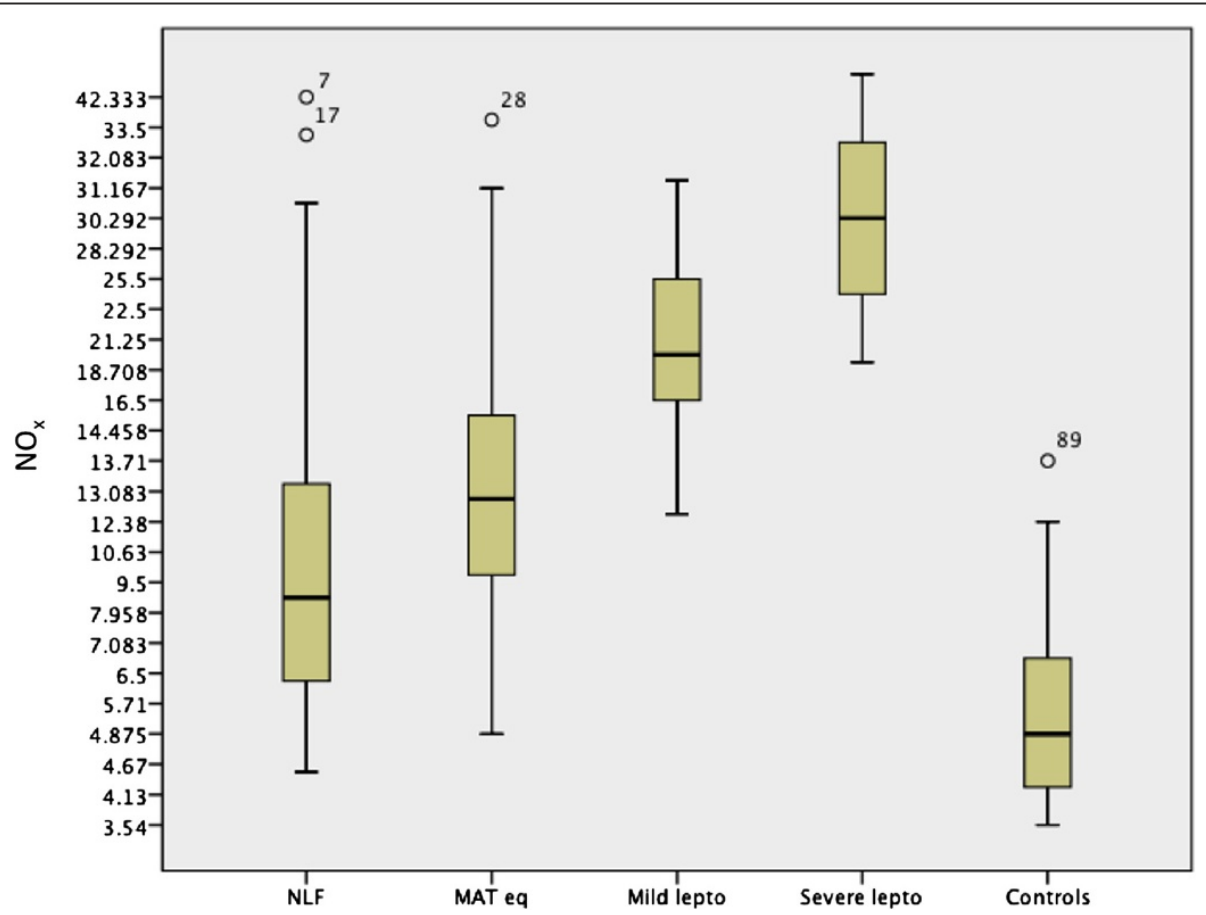

Figure 1 Serum $\mathrm{NO}_{\mathbf{x}}$ levels in different patient groups and healthy controls. NLF: Non-leptospirosis fever; MAT Eq: MAT equivocal patients. lepto: leptospirosis. 
Table $4 \mathrm{NO}_{\mathrm{x}}$ values in the different categories

\begin{tabular}{lccrr}
\hline Category & N & Mean & SD & SEM \\
\hline Confirmed leptospirosis & 40 & 28.247 & 11.425 & 1.806 \\
\hline Severe leptospirosis & 26 & 32.071 & 11.773 & 2.309 \\
\hline Mild leptospirosis & 14 & 21.146 & 6.441 & 1.722 \\
\hline MAT equivocal & 27 & 14.032 & 7.579 & 1.459 \\
\hline Non-leptospirosis fever & 18 & 13.523 & 11.581 & 2.730 \\
\hline Healthy controls & 23 & 6.078 & 2.802 & 0.572 \\
\hline
\end{tabular}

levels were corrected for renal function, using the ratio $\mathrm{NO}_{\mathrm{x}} /$ Creatinine, $\mathrm{NO}_{\mathrm{x}}$ levels showed an inverse relationship with the severity of malaria. Corrected $\mathrm{NO}_{\mathrm{x}}$ levels were lowest in patients with severe disease, while higher levels were seen in controls as well as those with asymptomatic disease, suggesting that high $\mathrm{NO}_{\mathrm{x}}$ levels may protect against severe malaria. Furthermore, in a mouse model, Gramaglia et al. [26] demonstrated that low NO bioavailability contributes to the genesis of experimental cerebral malaria.

Although many confounding factors could be present, the finding that corrected $\mathrm{NO}_{\mathrm{x}}$ levels are low in clinically severe leptospirosis is itself of significance. Whether

\begin{tabular}{|c|c|c|c|c|}
\hline (I) Category & (J) Category & Mean difference (I-J) & Std. error & Sig. \\
\hline \multirow[t]{4}{*}{ NLF } & MAT eq & -.026593 & .020710 & 1.000 \\
\hline & Mild Lepto & $-.087484^{*}$ & .024253 & .005 \\
\hline & Severe lepto & .029598 & .020869 & 1.000 \\
\hline & Controls & .019194 & .021222 & 1.000 \\
\hline \multirow[t]{4}{*}{ MAT eq } & NLF & .026593 & .020710 & 1.000 \\
\hline & Mild Lepto & -.060892 & .022415 & .077 \\
\hline & Severe lepto & $.056191^{*}$ & .018701 & .033 \\
\hline & Controls & .045787 & .019094 & .183 \\
\hline \multirow[t]{4}{*}{ Mild lepto } & NLF & $.087484^{*}$ & .024253 & .005 \\
\hline & MAT eq & .060892 & .022415 & .077 \\
\hline & Severe lepto & $.117082^{*}$ & .022562 & .000 \\
\hline & Controls & $.106679^{*}$ & .022889 & .000 \\
\hline \multirow[t]{4}{*}{ Severe lepto } & NLF & -.029598 & .020869 & 1.000 \\
\hline & MAT eq & $-.056191^{*}$ & .018701 & .033 \\
\hline & Mild Lepto & $-.117082^{*}$ & .022562 & .000 \\
\hline & Controls & -.010404 & .019266 & 1.000 \\
\hline \multirow[t]{4}{*}{ Controls } & NLF & -.019194 & .021222 & 1.000 \\
\hline & MAT eq & -.045787 & .019094 & .183 \\
\hline & Mild Lepto & $-.106679^{*}$ & .022889 & .000 \\
\hline & Severe lepto & .010404 & .019266 & 1.000 \\
\hline
\end{tabular}

NLF: Non-leptospirosis fever, MAT eq: MAT equivocal patients, lepto: leptospirosis, Sig: significance. * denotes statistically significant differences.
$\mathrm{NO}_{\mathrm{x}}$ levels are low in severe leptospirosis as a result of endothelial dysfunction resulting from severe disease, or whether individuals in whom iNOS activity does not increase in response to infection are more likely to develop severe disease remains unclear. Another possibility is that iNOS activity is normal, but the NO produced is rapidly removed by other molecules such as reactive oxygen species and haemoglobin. The measurement of serial $\mathrm{NO}_{\mathrm{x}}$ levels and correlating these with the onset of organ dysfunction in patients with leptospirosis and in experimental models is likely to provide further insight into this issue.

The finding that corrected $\mathrm{NO}_{\mathrm{x}}$ levels in NLFs were similar to those seen in severe leptospirosis is interesting. NLFs presumably represent a heterogenous group, and a significant number in this group had renal dysfunction. Whether this suggests a decrease in $\mathrm{NO}_{\mathrm{x}}$ levels in infections which result in organ dysfunction is difficult to determine from this study. Clinical features similar to those of severe leptospirosis occur in many other infections, such as dengue, hanta-virus and acute hepatitis; some of the patients in the NLF and MAT equivocal groups did present with clinical features similar to severe leptospirosis; however numbers were too small for any realistic comparisons of NO levels in these subgroups to be possible.

The Griess reaction explained in the methodology is specific for nitrite levels in blood. Therefore in order to measure the nitrates, they had to be converted to nitrites. This conversion can be achieved with either a chemical or an enzymatic reduction and we opted for the chemical measure by treating the sera with Vanadium(III) chloride [7,14]. The use of Vanadium (III) chloride offers a low cost method compared to the enzymatic reduction and therefore the modified Griess assay is an inexpensive, simple, rapid, accurate and a sensitive method for measurement of $\mathrm{NO}_{\mathrm{X}}$ levels, better suited method for resource limited settings in developing countries.

\section{Limitations}

One of the limitations of this study is the confounding factors that can affect serum $\mathrm{NO}_{\mathrm{X}}$ levels such as age and diet [27]. However, the mean ages of the subjects in the different groups were comparable, and dietary influence was minimized by collecting samples in the early mornings prior to the intake of food. It was also possible that patients with severe disease had a lower dietary contribution of nitrites. This is very difficult to quantify in a clinical study, and no standard methods for quantification exist. However in our study, we compared the incidence and severity of symptoms such as nausea, vomiting and loss of appetite, and there was no difference in the incidence of these symptoms in severe 


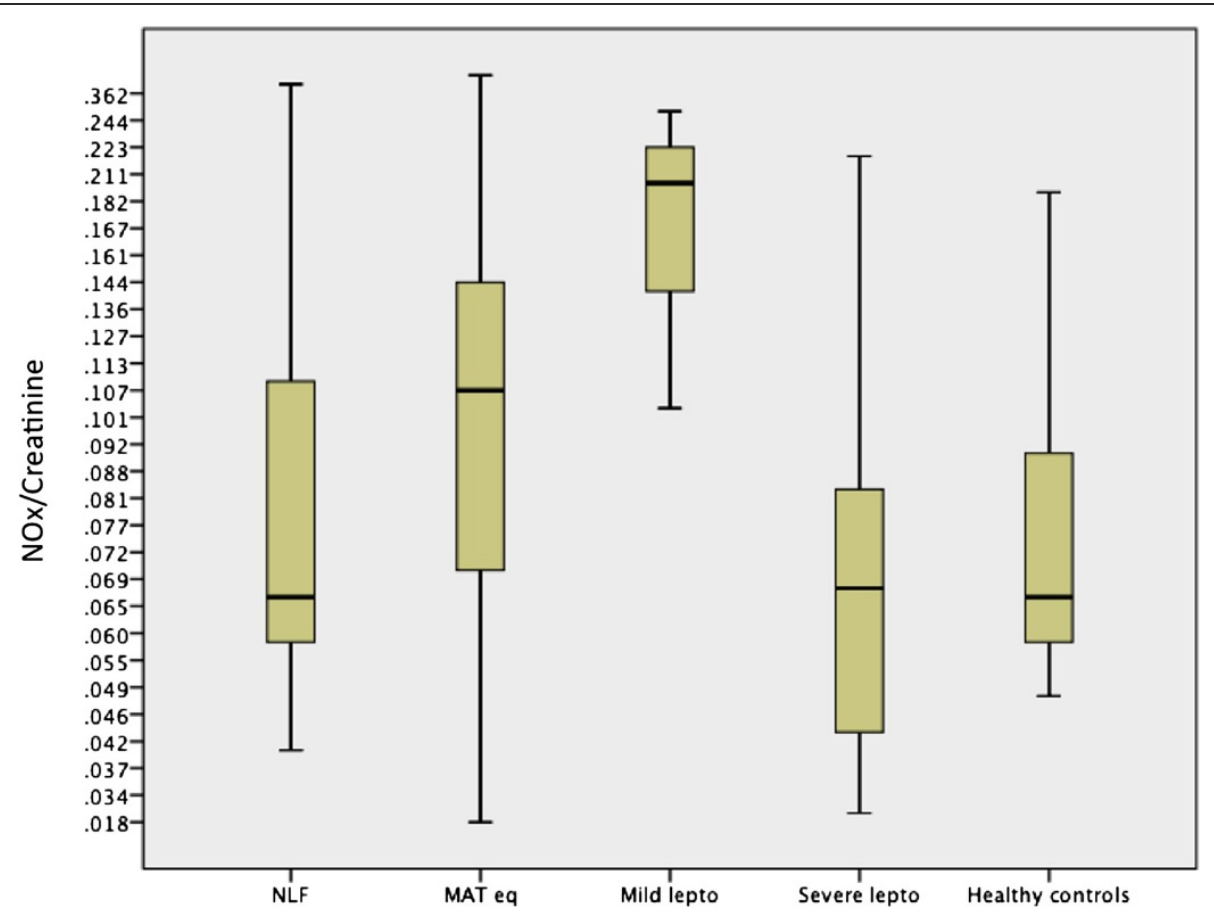

Figure 2 Corrected $\mathrm{NO}_{x}\left(\mathrm{NO}_{x} /\right.$ creatinine) in different patient groups and healthy controls. NLF: Non-leptospirosis fever; MAT Eq: MAT equivocal patients. lepto: leptospirosis.

disease compared with non-severe disease. All patients, even the sickest, were able to eat and drink. There was a gender bias in the sample with more males than females. However, this is a well established epidemiological fact in leptospirosis in Sri Lanka, as it is the males who engage more in outdoor activities such as farming which is a major occupational risk factor for leptospirosis [21]. Of the serological tests to diagnose leptospirosis, MAT is the preferred method, and it is also the test recommended by the epidemiology unit of the Ministry of Health in Sri Lanka [21]. However, MAT serology may be insensitive in early acute-phase specimens [28]. Moreover, patients with fulminant leptospirosis may die before seroconversion occurs. A four-fold rise in MAT titer would have helped to differentiate patients with true leptospirosis in the MAT equivocal group [22,29]. However, many patients did not return for follow up

Table $6 \mathrm{NO}_{\mathrm{x}} / \mathrm{creatinine} \mathrm{levels} \mathrm{in} \mathrm{the} \mathrm{different} \mathrm{study}$ groups

\begin{tabular}{lllll}
\hline Category & N & Mean & SD & SEM \\
\hline Confirmed leptospirosis & 40 & 0.113 & 0.074 & 0.012 \\
\hline Severe leptospirosis & 26 & 0.072 & 0.042 & 0.008 \\
\hline Mild leptospirosis & 14 & 0.189 & 0.058 & 0.015 \\
\hline MAT equivocal & 27 & 0.128 & 0.096 & 0.018 \\
\hline Non-leptospirosis fever & 18 & 0.101 & 0.085 & 0.020 \\
\hline Healthy controls & 23 & 0.082 & 0.038 & 0.008 \\
\hline
\end{tabular}

visits after discharge and we had to restrict the leptospirosis confirmed group to those with high MAT titers $\geq 400$. We did not obtain serial $\mathrm{NO}_{\mathrm{x}}$ measurements in patients (due to logistical difficulties and limited resources) which would have enabled us to predict the earliest point at which $\mathrm{NO}_{\mathrm{X}}$ levels would start to differ in those with severe disease, thus establishing the approximate earliest point it would be useful as a predictive marker. Based on the results of this initial study a larger multi-centre study was designed by us, and is currently in progress.

\section{Conclusions}

This study shows that crude serum $\mathrm{NO}_{\mathrm{X}}$ levels were significantly elevated in Sri Lankan patients with leptospirosis compared to healthy controls and nonleptospirosis fever patients; however once $\mathrm{NO}_{\mathrm{x}}$ levels were corrected for serum creatinine, the relationship between $\mathrm{NO}_{\mathrm{x}}$ levels and disease severity was shown to be strikingly different. Corrected $\mathrm{NO}_{\mathrm{x}}$ levels were significantly suppressed in patients with severe leptospirosis. Thus, $\mathrm{NO}_{\mathrm{x}}$ levels in patients with leptospirosis may be useful to predict severe disease, i.e., the presence of low $\mathrm{NO}_{\mathrm{x}}$ levels (after correction for renal function) in leptospirosis may predict the development or organ dysfunction. We also demonstrated that chemical conversion of nitrates to nitrite with Vanadium (III) chloride and 
measuring of $\mathrm{NO}_{\mathrm{X}}$ levels (modified Griess reaction) is a relatively cheap assay technique that can be employed in resource limited settings.

\section{Abbreviations}

NO: Nitric oxide; $\mathrm{NO}_{\mathrm{x}}$ : Total nitrites and nitrates; MAT: Microscopic agglutination titre; iNOS: Inducible nitric oxide synthatase; NLF:

Non-leptospirosis fever; WHO: World Health Organisation; MODS: Multi-organ dysfunction syndrome; ELISA: Enzyme-linked immunosorbent assay: NHSL: National Hospital, Colombo, Sri Lanka.

\section{Competing interests}

The authors declare that they have no competing interests.

\section{Authors' contributions}

SR, SMH, HJDS and TK developed the initial concept for the study. TK and TV collected clinical data and samples. TK and SMH performed the laboratory measurements. PS performed leptospirosis diagnostic serology. SR, SMH, TK and CR analysed the data. TK, CR, SMH and SR wrote the first draft. All authors read and approved the final manuscript.

\section{Authors' information}

TK(MSc) was an MSc Research Student, and SMH(PhD) is Senior Lecturer, at the Institute of Biochemistry, Molecular Biology, and Biotechnology (IBMBB). PS(MD) is Consultant Microbiologist at the Medical Research Institute, Colombo. HJDS(MD,FRCP,DPhil) is Senior Professor in the Dept of Medicine, University of Kelaniya. TV(MBBS) was Research Associate, CR(MBBS, MD) is Lecturer, and SR (MD,FRCP) is Professor in the Dept of Clinical Medicine, University of Colombo. SR(MD,FRCP), SMH(PhD) and HJDS(MD,FRCP,DPhil) are senior researchers currently supervising a series of studies on leptospirosis

\section{Acknowledgements}

We thank Ms Ratnamali Perera and Ms Thameesha Gamage of the Department of Microbiology, Medical Research Institute, Colombo, Sri Lanka for their help with MAT testing, the staff of National Hospital Sri Lanka for helping with patient data and providing patient care, and the Institute of Biochemistry, Molecular Biology and Biotechnology, University of Colombo for facilitating this study.

\section{Author details}

${ }^{1}$ Institute of Biochemistry, Molecular Biology and Biotechnology, University of Colombo, Colombo, Sri Lanka. ${ }^{2}$ Department of Clinical Medicine, Faculty of Medicine, University of Colombo, Colombo, Sri Lanka. ${ }^{3}$ Medical Research Institute, Colombo, Sri Lanka. ${ }^{4}$ Department of Medicine, Faculty of Medicine, University of Kelaniya, Kelaniya, Sri Lanka.

Received: 26 November 2012 Accepted: 1 May 2013

Published: 6 May 2013

\section{References}

1. Cachay ER, Vinetz JM: A global research agenda for leptospirosis. J Postgrad Med 2005, 51(3):174-178.

2. The Global Burden of Leptospirosis. WHO Leptospirosis Burden Epidemiology Reference Group (LERG) http://www.who.int/zoonoses/diseases/lerg/en/ index2.html. Accessed October.05.2013.

3. Chawla V, Trivedi TH, Yeolekar ME: Epidemic of leptospirosis: an ICU experience. J Assoc Physicians India 2004, 52:619-622.

4. Abdulkader RC, Silva MV: The kidney in leptospirosis. Pediatr Nephrol 2008 , 23(12):2111-2120.

5. Spichler AS, Vilaca PJ, Athanazio DA, Albuquerque JO, Buzzar M, Castro B, Seguro A, Vinetz JM: Predictors of lethality in severe leptospirosis in urban Brazil. AmJTrop Med Hyg 2008, 79(6):911-914.

6. Rajapakse S, Rodrigo C, Hannifa R: Predictors of mortality in severe leptospirosis; a concept paper on developing a clinically relevant classification. J Emerg Trauma Shock 2010, 3:213-219.

7. Davis JS, Anstey NM: Is plasma arginine concentration decreased in patients with sepsis? A systematic review and meta-analysis. Crit Care Med 2011, 39(2):380-385.
8. Prada J, Kremsner PG: Enhanced production of reactive nitrogen intermediates in human and murine malaria. Parasitol Today 1995 11(11):409-410.

9. Kremsner PG, Winkler S, Wildling E, Prada J, Bienzle U, Graninger W, Nussler AK: High plasma levels of nitrogen oxides are associated with severe disease and correlate with rapid parasitological and clinical cure in Plasmodium falciparum malaria. Trans R Soc Trop Med Hyg 1996, 90(1):44-47.

10. Al Yaman FM, Mokela D, Genton B, Rockett KA, Alpers MP, Clark IA: Association between serum levels of reactive nitrogen intermediates and coma in children with cerebral malaria in Papua New Guinea. Trans R Soc Trop Med Hyg 1996, 90(3):270-273.

11. Anstey NM, Weinberg JB, Hassanali MY, Mwaikambo ED, Manyenga D, Misukonis MA, Arnelle DR, Hollis D, McDonald MI, Granger DL: Nitric oxide in Tanzanian children with malaria: inverse relationship between malaria severity and nitric oxide production/nitric oxide synthase type 2 expression. J Exp Med 1996, 184(2):557-567.

12. Prada J, Kremsner PG: Reactive nitrogen intermediates and cerebral malaria. Trans R Soc Trop Med Hyg 1997, 91(1):92-93.

13. Anstey NM, Granger DL, Weinberg JB: Nitrate levels in malaria. Trans $R$ SoC Trop Med Hyg 1997, 91(2):238-240.

14. Maciel EA, Athanazio DA, Reis EA, Cunha FQ, Queiroz A, Almeida D, McBride $\mathrm{AJ}, \mathrm{Ko}$ Al, Reis MG: High serum nitric oxide levels in patients with severe leptospirosis. Acta Trop 2006, 100(3):256-260.

15. Moshage $H$, Kok B, Huizenga JR, Jansen PLM: Nitrite and nitrate determinations in plasma: A critical evaluation. Clin Chem 1995, 41:892-896.

16. Groeneveld PHP, Kwappenberg KMC, Langermans JAM, Nibbering PH, Curtis $\mathrm{L}$ : Relation between pro-and anti-inflammatory cytokines and the production of nitric oxide (NO) in severe sepsis. Cytokine 1997, 9:138-142.

17. Granger DL, Anstey NM, Miller WC, Weinberg JB: Measuring nitric oxide production in human clinical studies. Methods Enzymol 1999, 301:49-61.

18. Mackenzie IM, Ekangaki A, Young JD, Garrard CS: Effect of renal function on serum nitrogen oxide concentrations. Clin Chem 1996, 42(3):440-444.

19. Mehta RL, Kellum JA, Shah SV, Molitoris BA, Ronco C, Warnock DG, Levin A: Acute Kidney Injury Network: report of an initiative to improve outcomes in acute kidney injury. Crit Care 2007, 11(2):R31.

20. Gunaratna RI, Handunnetti SM, Bulathsinghalage MR, Somaratne P, Jayanaga A, de Silva HJ, Rajapakse S: Serum nitrite levels in Sri Lankan patients with leptospirosis. Asian Pac J Trop Med 2012, 5:75-78.

21. An interim analysis of Leptospirosis outbreak in Sri Lanka-2008. Colombo Epidemiology Unit, Ministry of Health Care and Nutrition, Sri Lanka; 2008

22. World Health Organization: Human Leptospirosis. Guidance for diagnosis surveillance and control. Geneva: World Health Organization; 2003.

23. Cumberland P, Everard CO, Levett PN: Assessment of the efficacy of an IgM-elisa and microscopic agglutination test (MAT) in the diagnosis of acute leptospirosis. Am J Trop Med Hyg 1999, 61(5):731-734.

24. Miranda KM, Espey MG, Wink DA: A rapid, simple spectrophotometric method for simultaneous detection of nitrate and nitrite. Nitric Oxide 2001, 5:62-71

25. Ghasemi A, Hedayati M, Biabani H: Protien precipitation methods evaluated for determination of serum nitric oxide end products by the Griess assay. Journal of Medical Science Research 2007, 2:29-32.

26. Gramaglia I, Sobolewski P, Meays D, Contreras R, Nolan JP, Frangos JA, Intaglietta M, van der Heyde HC: Low nitric oxide bioavailability contributes to the genesis of experimental cerebral malaria. Nat Med 2006, 12(12):1417-1422.

27. Toprakçi M, Ozmen D, Mutaf I, Turgan N, Parildar Z, Habif S, Güner I, Bayindir O: Age-associated changes in nitric oxide metabolites nitrite and nitrate. Int J Clin Lab Res 2000, 30:83-85.

28. Levett PN: Leptospirosis. Clin Microbiol Rev 2001, 14(2):296-326.

29. Levett PN, Branch SL, Whittington CU, Edwards CN, Paxton H: Two methods for rapid serological diagnosis of acute leptospirosis. Clin Diagn Lab Immunol 2001, 8(2):349-351.

doi:10.1186/1471-2334-13-206

Cite this article as: Kalugalage et al.: Low serum total nitrite and nitrate levels in severe leptospirosis. BMC Infectious Diseases 2013 13:206. 